\title{
Horizons/Théâtre
}

Revue d'études théâtrales

$14 \mid 2019$

Les arts du spectacle dans l'Afrique subsaharienne - 2

\section{Okumkpo Masquerade Concert: Traditional Public Theatre and Social Commitment in Afikpo, Southeastern Nigeria}

Richard Oko Ajah

\section{(2) OpenEdition}

Journals

Electronic version

URL: https://journals.openedition.org/ht/1583

DOI: $10.4000 /$ ht. 1583

ISSN: 2678-5420

Publisher

Presses universitaires de Bordeaux

Printed version

Date of publication: 1 January 2019

Number of pages: 92-107

ISBN: 979-10-300-0718-3

ISSN: 2261-4591

Electronic reference

Richard Oko Ajah, "Okumkpo Masquerade Concert: Traditional Public Theatre and Social Commitment in Afikpo, Southeastern Nigeria", Horizons/Théâtre [Online], 14 | 2019, Online since 01 June 2022, connection on 30 June 2022. URL: http://journals.openedition.org/ht/1583 ; DOI: https://doi.org/ $10.4000 /$ ht. 1583

\section{c) $(7) \Theta$}

La revue Horizons/Théâtre est mise à disposition selon les termes de la Licence Creative Commons Attribution - Pas d'Utilisation Commerciale - Pas de Modification 4.0 International. 


\section{RICHARD OKO AJAH}

Richard Oko Ajah teaches literature, criticism and French language in the Department of Foreign Languages at the University of Uyo in Nigeria where he graduated with First Class and with several awards. He obtained M.A with distinction and Doctorate degrees from the University of Ibadan, Nigeria as ETF Scholar. Dr. Ajah's areas of specialization are comparative, African and Maghrebian literatures, cultural studies, francophone films, postcolonial studies, graphic novels, travel writing and the digital humanities. He is a published poet and a coeditor of Language and Literature in the Dis/Service of Humanity (2016).

richardajah@uniuyo.edu.ng

Abstract: As an ethnical subgroup of Southeastern Nigeria, Afikpo has a cultural heritage that showcases its rich oral traditions and from where emerge its philosophy, mythology and religiosity. Sociological researches have unveiled the people's ethnography and treated superficially their oral traditions. For example, Okumkpo community theatre prioritize its entertaining performance over its guided responsibility of community watchdog. From literary perspective that is built on some ideological and epistemological underpinnings of "théâtre engagé", this study considers Okumkpo masquerade as a public theatre with social commitment. The masked major performer/character plays a role of a social commentator, critic and activist, thereby becoming a sacred actor who promotes moral growth and justice in Afikpo social space. It takes place in an open space

Résumé: En tant que sous-groupe ethnique du sud-est du Nigéria, Afikpo possède un patrimoine culturel qui met en valeur ses riches traditions orales et d'où émergent sa philosophie, sa mythologie et sa religiosité. Des études sociologiques ont interrogé l'ethnographie du peuple et traité superficiellement ses traditions orales. Par exemple, le théâtre communautaire d'Okumkpo donne ainsi la priorité à sa performance divertissante plutôt qu'à sa responsabilité artistique de critique communautaire. Dans une perspective littéraire basée sur des fondements idéologiques et épistémologiques du " théâtre engagé ", cette étude considère la performance masquée d'Okumkpo comme un théâtre public avec engagement social. L'acteur/personnage principal masqué jove un rôle de commentateur social, critique et activiste, devenant ainsi un acteur sacré qui promeut la moralité et la justice dans l'espace called Ogo and it combines drama and dance, rhetoric and gestures, and humor and songs from. This work raises language and gender issues which, combined with the theatre's ritualized performance, pose a threat to the survival of this oral tradition. Okumkpo's risk of extinction is strongly premised on its gendered cast that makes its masked actors homogenously masculine with heterogenous public. This paper proposes that demythologization and partial feminization of Okumkpo masquerade would increase its cultural acceptability while the introduction of English and other international languages as its language of performance would enhance its eventual cultural commodification.

KeYwords: Okumkpo, Social commitment, Oral tradition, Afikpo, Mask performance.

social d'Afikpo. II se déroule dans un espace public appelé $O g o$ et combine le drame et la danse, la rhétorique et les gestes, et l'humour et les chansons. Cet article soulève des questions de langue et de genre qui, combinées à la performance ritualisée du théâtre, constituent une menace pour la survie de cette tradition orale. Le risque d'extinction d'Okumkpo est fortement fondé sur son casting sexué qui rend ses acteurs masqués homogènes masculins avec un public hétérogène. Cette étude propose que la démythologisation et la féminisation partielle d'Okumkpo augmenteraient son acceptabilité culturelle tandis que l'introduction de l'anglais et d'autres langues internationales comme langue d'interprétation améliorerait son éventuelle marchandisation culturelle.

Mots-cLÉs : Okumkpo, engagement social, tradition orale, Afikpo, masque. 


\section{Okumkpo Masquerade Concert: Traditional Public Theatre and Social Commitment in Afikpo, Southeastern Nigeria}

\section{Introduction}

AFrican CUlTURAL HERITAge IS COMPOSITE OF ITS LITERATURE, art and culture from where emerge its philosophy, mythology and religion. African oral traditions reflect African primordial civilization, though Eurocentric stereotypes see them as primitive and superstitious. Despite criticism on the weakness of orature such as the inherent problems of relying on human memory, questions of chronology, distortion, individual biases and group prejudices (Chuka, 2001), African writers continue to deploy it as raw materials used for literary creativity (Ojaide, 2009; Kehinde, 2003) winning awards and accolades in the world. Proverbs, myth, legends and tales as genres of African oral literature are now incorporated into modern written literature. Kesteloot (1978) refers to African oral literature as a literature presented in African languages and transmitted directly from the head that invents it to the heart that receives it. Nonetheless, it is undeniable that oral tradition remains the fundamental source of African historiography, as the paradigmatic relationship between memory, tradition and history cannot be over-emphasized (Attikpoé, 2009, p. 153). It should be known that "oral historians confront issues concerning both the validity of oral transmission as history and the responsibility toward their informants" (Shuman, 2003, p. 130). As custodians of African philosophy, oral traditions shape ideas and ideologies of African writers whose literary works become mosaic of western and indigenous forms. Each traditional society has its philosophy embedded in its folklore, be it of the Mandingos, the Yorubas, the Bantus, the Fantis, the Ashantis, the Ibos, the Ewe-Fonts, or the Akans. Coker \& Coker (2008) observe the significance of folklore in generating laws governing intra and inter-personal relationships, communal cohesion, ethical regime and justice system among the Yoruba indigenous system of knowledge. Such traditional laws, written on the consciences of the folk, now exist as written texts of modern constitutions of African nations. Since European colonization of Africa, oral traditions have become "endangered species", risking extinction and an- 
nihilation, except that most of them are now chronicled as written literature. Literate cultures, which stress the visual, store knowledge in written and other kinds of documents, provided by recording and retrieval technologies. Oral cultures, in contrast, encode knowledge in a popular communal memory (Tomaselli \& Eke, 1995). However, African oral tradition is now undergoing what Adejumo (2009) calls "technologizing" which enables the restoration, documentation, processing and storage of oral traditions as a panacea for their endangerment. Okumkpo and other forms of Afikpo oral literature remain under threat of extinction as much effort has not been done towards its documentation. Aside documentation, ritual, language and gender issues, as it will be shown in this work, also endanger the survival of Afikpo Okumkpo masquerade and its performance. The hallmark of this paper is the analysis of Okumkpo masked theatre of Afikpo people of Southeastern part of Nigeria as a part of Afikpo oral literature. We rely on primary and secondary sources of information. As an initiated indigene of Afikpo, the primary source of this research consists of personal interviews and participation as a spectator and mock performer, while our secondary sources of information include literature of related journal articles, ethnographical works, books and films.

\section{Afikpo and its Traditional Cultural Heritage}

Afikpo is an ethnical subgroup in Southeastern Nigeria and one of the numerous small confederations of villages in Ibo country (Ottenberg, 1968). Afikpo Town is typically a composite nucleated village-group or conglomeration of thirty villages collectively called Afikpo village-group (Aja, 2005). Afikpo is an ancient town; several archeological findings support the claim that Afikpo civilization existed as far as the Neolithic age (Elechi, 2003). NdiEhugbo (Afikpo people) have a rich cultural heritage which includes folk literature, pottery and wrestling, New Yam festival, Iko festival, Ehoma Fishing festival, Okumkpo community theatre, among others. All these oral traditions define the identity of Ndi Ehugbo, Afikpo people and their Afikponess. Simon and Phoebe Ottenberg are the most important researchers who have contributed specifically to the study of Afikpo Ibo society (Cheng Chang, 1980). Such anthropological researches (see Ottenberg, 1968; Cheng Chang, 1980) and historical works (Aja, 2005) clearly show the ethnography of Afikpo and its rich cultural heritage. However, there is no exposition on literary forms and contents of Afikpo oral literature because of the socio-historical perspective of the scholars'works, except Ottenberg's Masked Rituals in Afikpo (1970) that captures the Okumkpo masked performance with its cathartic 
effects on Afikpo traditional agrarian society. Characteristically, Afikpo oral tradition comprises of different traditional forms of legends, myths, epics, tales, and proverbs among others, revealing the ancestry, philosophy and mythology of Afikpo Ibo society. Legends of Igbo Ukwu, Ohaodu and Egu, tales of migration of origin and myths of Ajiberekwukwu are recycled through oral communication with different versions. For example, the consideration of Okumkpo public theatre from its cathartic perspective is minimalist, because it prioritizes its entertaining performance over its guided responsibility of community watchdog or "social seer". From literary perspective, this study considers Okumkpo masquerade as a public theatre with social commitment. It is a public because of its open-air setting in a sacred playground called $O g o$ and its destination to commoners. It can be considered as a "committed" traditional masked performance that checkmates the moral excesses of people in Afikpo socio-cultural community. For Osundare (2007), literary commitment is not mere abstract aesthetics, but a single-minded dedication to the battle for social change. Analogous to committed literature in its traditional form, Okumkpo's lead performer/actor has a tripartite function of social commentator, critic and activist. As we shall shortly see, Okumkpo masquerade theatre derives its aesthetics from the formulaic mixture of dance and drama, rhetoric and gestures, and songs and humor.

Afikpo has its dialect, Ehugbo language which is spoken by all confederating villages. Oral traditions, including Okumkpo, are presented in local vernacular which is hardly understood by other Ibo communities in Eastern Nigeria. To open up Afikpo oral traditions to other world, there must be a rethinking on the issue of language. Aside the case for the demythologization and feminization of Okumkpo masquerade performance which this paper will be making shortly, the linguistic aspect of traditional performances in a modern setting must be reconsidered. English language can be adopted as a medium of communication in Afikpo oral performances (wrestling, mbe, Ehoma fishing festival, Okumkpo masquerade and others); it will engender transcultural and transnational participation and boost their social functions. It is true that such total overhauling of linguistic aspect of Afikpo oral traditions could undermine the supernatural import of the performances. Therefore, this paper suggests that songs, prayers and dances can be rendered in Afikpo dialect as local colors to performances, but dialogues and monologues can be presented in English as Nigerian official language. Moreover, the use of interpreters can be promoted to bridge the gap between the performance and the foreign spectators who come to see Okumkpo as the most popular oral performance in Afikpo, South-eastern Nigeria. 


\section{Okumkpo Public Theatre: Form and Content}

Among all Afikpo oral traditions, the Okumkpo appears to be the most endangered as its production has apparently ceased in modern times. It can be referred to as public theatre with its pragmatic receptionalism, term used to "embody the processes employed by audiences to interpret and appreciate oral performances" (Khan, 2009, p. 144). Ottenberg (1970, p. 67) calls it "community theatre" and a "morality play" which "stresses traditional values and upholds personal and general standard of behavior and cooperation" (pp.74-75). It can be called a traditional theatre because of its unwritten scripts and local instruments. Musa (2006) admits that there is a thin difference between theatre and drama as both of them share a generic ontology. He defines them as thus:

Drama is a 'form of literature'which demonstrates, celebrates, recreates, reproduces, imitates and expresses the cultural essence of man and as a verifiable act of presentation, and that which is a 'performance on stage'... Theatre is also the (organized or unorganized) social-cultural, religious and political activities with numerous nomenclature: a seeing place, a performance and entertainment... (p. 216)

Okumkpo falls under Musa's categorization as a traditional theatre which involves performance, intended to entertain the audience. Jacob (2012, p. 16) summarizes theatre as "the art of packaging and presenting live performance before a live audience". Although Okumkpo masquerade is presented as a live performance, it possesses the qualities of a drama by its four basic dramatic elements, namely, the script which is oral, the actors who are masquerades, the stage which can be a sacred ground and the audience which comprises of initiates and non-initiates, males and females, children and the aged, and indigenes and foreigners. Okumkpo is typically theatrical and dramatic; its dramatic representation entails "speech, music, ritual, song as well as dance and mine" which Clark (1981, p. 57) also uses to identify traditional drama in Nigeria. This paper will use interchangeably the notions of drama and theatre, being fully aware of their ontological differences.

Okumkpo masquerade is the most popular and well attended Afikpo masked performance performed in form of a play that entertains its audience. it can be compared to Thai Nooraa, a genre of traditional performance art that is found in Southern Thailand and Northern Malaysia, combining "dance, music, singing, narrative verse, theatrical play, sorcery and ritual" (Iwasawa, 2008 , p. 2), except Okumkpo does not wholly involve sorcery or magic but personal and public ritualistic preparations. Okumkpo consists of a series of skits, songs and dances presented by masked players in the main common 
of a village (Cheng Chang, 1980). The performance belongs to what Suh (2002) refers to as sacred dramas which "are in turn sub-divided into ancestral or myth plays, masquerades or plays by age groups and cults, rituals, etc." (p. 371). As a folkloric art, Okumkpo is "an embodiment of the way [Afikpo] people see the world and the belief patterns of the culture in which they exist" (Khan, 2009, p. 149); it is part of "African indigenous dramatic traditions" which is used "to express and highlight contemporary problems and sensibility” (Agovi, 1990, p. 1). Each village Ogo cult puts on a series of public plays and dances between October and February that is the harvest and ceremonial period at Afikpo when the pleasant climate encourages ritual performance (Ottenberg, 1970, p. 68). This oral performance is preceded by oral announcements which serve as traditional publicity in nearby villages and towns. Audience, comprising of children, youth and adults, is formed from different Afikpo federating villages and neighboring towns, interested in Okumkpo masquerade performance and its humoristic presentations.

Like every theatre, Okumkpo is made up of group of masked performers who also constitute its major and minor actors. Okumkpo cast wears masks, specially designed by traditional artists. Costumes are defined by roles that each performer or actor plays. Nnade Okumkpo is the major actor, organizer and director who plays the lead role, doubling as the vocalist and narrator whose rhetoric prowess defines his oratory heritage and remains unparalleled. Comparable to a francophone griot, he knows family genealogies, village history, and private and public exploits. In addition, this gifted local artist chronicles social events and human evils in the community because Okumkpo remains a product of factographics that is the use of documentary materials in the structure of a novel/fiction (Huttunen, 2002). Unlike Afikpo Ogo masquerade called Okpaa whose costume is made from native fiber or from European cord, Okumkpo masquerade wears a costume made from wood, raffia and other materials and dons "a simple, long, oval mask, with the face quartered in dark brown and white details rendered in opposite colors. Broken egg shells [are] applied to give texture and effect to the mask" (Onwuzolum, 1977). He can be called in the words of Ododo (2001, p. 2) a "raconteur masquerade". His narrative is mixed up with intermittent songs and dances, accompanied with drums and other traditional musical instruments. The lead performer's rhetoric is interlaced with choruses that divulge the thematic of the theatre. Barrios (1997) admits that "the integrated connection of music and dance is an inherent part of African based dramatic communication" (p. 9). Feminine in costume, Agbogo Okumkpo wears a feminine mask and make-up, dressed stylishly and gorgeously to arouse the admiration of 
audience. Her bangles, chain of bells and other accessories create a rhythmic symphony with her womanly steps. Her materialization before the audience is one of the climaxes of the performance that is always intriguing.

The performance comes after a long period of rehearsals, costume making or hiring and other paraphernalia, while the stage does not need a special preparation or decoration; it is normally open-air performance in a public square or Ogo playing ground. Such grounds are deemed sacred and deserve communal respect, yet they contend with tensions and excitement built during the course of the performance, as spectators swell forward, breaking the boundary and shrinking the space, obvious to the shouts and exertions of the crowd-controllers (Shivers, 2009). The traditional masquerade performance is a sacred product of Afikpo Ogo cult who organizes it. Initiation into the Ogo cult promotes status of the initiated person who now has access to indigenous mysteries and myths, and to the "spirit world". In the same vein, Okumkpo masks can only be worn by Afikpo indigenes initiated into the cult; non-initiates are not permitted as they are considered as women in traditional milieu.

Back to the factographical nature of Okumkpo masquerade, the traditional drama derives its themes or preoccupation from a series of social events, ranging from human evils and wickedness to socio-cultural predicaments. During the Ozizza community Okumkpo masquerade, Engr. Eze O. Eze and a road construction company, Guffanti were skits that unveiled the secret of Otu Eke/Ozizza Beach road construction. The masquerades narrated that the road could not be completed due to the corruption of Guffanti engineers and Imo State Government functionaries which Engr. Eze as the then Commissioner for Works and Transport represented. Okumkpo openly indicted Engr. Eze, an indigene of Afikpo. The former Commissioner struggled to exonerate himself from this allegation and the public dishonor it precipitated. He would have sought legal redress if Okumkpo were to be "humans". The masked characters normally demonstrate an event through songs and dances to amuse the audience, while Nnade Okumkpo who doubles as the narrator and lead singer narrates the story. Ottenberg (2005, p. 96) narrates his experience of Afikpo Okumkpo masquerades in these words:

I never sew an Okumkpo play where they made fun of me when I was there, but I heard that they did when I was not around. I did see them make fun of a Catholic priest once. This was a skit about a man who was ill all the time. He went from diviner to diviner but did not get better. This was acted out while being sung by the Okumkpo leaders. Finally, the sick man went to a Catholic priest, played by another masked figure. The man bowed down before the priest who touched him on the head and prayed in English. Then the young man jumped up and was cured 
and went around shouting "my Father who art in heaven!" "My Father who art in Heaven!" over and over again. But he could not speak Igbo anymore!

Ottenberg's narrative, though it happened so many years ago, remains an eye-opener to the themes of Okumkpo masquerade performance in Afikpo. The object of this skit would have been to show the danger of Western religion and its negative effects on indigenous cultures, though the masquerades did not deny the power of Christianity as exemplified in the scene where the Catholic priest's prayers healed the native sick man. The story attempts to admonish the indigenes against abandoning the culture after getting cured through the White man's religion. The acting out of the sick man's encounter with the Catholic priest shows the deployment of imitation; the seemingly moral lessons appear to be enlightenment on Afikpo culture and to Afikpo people ; and the songs and dances that accompany the narrative produce the entertainment aspect of the performance. From the analysis, it can be seen that Okumkpo masquerade performance qualifies for a drama whose essentials Rotimi (1981, p. 78) identifies as imitation, enlightenment and entertainment.

\section{The Myth of Masks and Social Commitment}

The masks above originate from Afikpo where they are used during village festivals and entertainments on days dedicated for masquerading by initiates of $O g o$ cults who are traditionally licensed custodians of the masks. Surrounded by cultural and spiritual myths, masks are said to be harmful to non-initiates who are not permitted to wear or hold them. However, the non-initiates or enas have their own masks used in minor masquerading in their group of non-initiates called Ohia umuena, though such masquerades have no supernatural myths attached to them. All masks are handiworks of traditional carvers and painters; they are generally made from wood. Some have flat broad superstructure and others have peglike projections and curved blade form on the top, all painted with different colors. The extensions, made of traditional materials, to the masks enable them to sit tight on the face of the masquerade and to permanently conceal the identity of the wearer. It is the festival or entertainment that determines the type of mask and masquerade shown to the curious public of non-initiates and womenfolk who form its primary audience, except in the case of Okumkpo public theatre that attracts both initiates, non-initiates and women of the community.

Eke and Orie are days in calendar system of Afrikpo traditional society. Okpaa and Lugulu masquerades are only dedicated to these days respectively. Njenje masquerade can only be seen during I ko periodic festivals held in all fe- 
derating communities of Afikpo society between November and December. No masquerade comes out during the raining season; it is purely an event of dry season after ichu aho, typical of New Year celebration in Afikpo. Nnade and Agbogo Okumkpo are masked performers that grace the Okumkpo performance as seen in Okumkpo Unwana, held on Friday, December 31, 2004 at Ogo Unwana (Town square), an event that witnessed an unprecedented crowd of enthusiastic spectators troop out en masse to watch a thrilling performance (Afikpo Today, 2005, p. 17).

In practice and performance, masked theatre creates illusion of reality through the deployment of theatrical elements such as the use of facial disguise, costume, body decoration, props, movements, vocalization, drumming and dancing, thereby presuming a structure of belief (Shivers, 2009). Masquerades are therefore called Mmonwu ("spirit") in Igboland. Mmonwu or maa in Afikpo stems as a gloss from mmuo onwu (lit. "spirit-dead"), highlighting that the masquerade is a temporary embodiment in the material world from the world of the dead (Gore, 2008, p. 62). Oral literature serves to conceive, create, and codify the myth which a culture stands upon (Lambert, 2005). In essence, masquerades (like Okumkpo) and myth demonstrate connections that are rooted to the imaginative syntax of the folk through cross-cultural motif (Hunte, 2007, p. 59). Masks mystify the play, underscore the sacredness of its message and demonstrate the masquerade's paradigmatic relationship with mythology. Olorunyomi (1996) calls mask a code that "is capable of embodying both sacred and profane contents" (p. 63). It is the mask's sacredness that consolidates the masquerade message in Afikpo orature, especially in Okumkpo performance. The theatre becomes a center "where the metaphysical action of spirits can be represented through masking” (Okafor, 1991, p. 43). In plain words, the mask is not a form of deceit or just for concealment, but a personification of spiritual power and authority (Obuh, 2005, p. 2). Afikpo Okumkpo public theatre is a performance of masked characters that demonstrates the paradigmatic existential relationship between the living and the dead, and the natural and the supernatural in Afikpo traditional society. The mask gives an air of spiritualism and supernaturalism to the performer who enters into anonymity, thereby separating the personality from the persona. In the words of Okafor (1991), masks serve as an "instrument of disguise" and as "the principal device in the invocation of the supernatural” (p. 44) which forms the people's system of indigenous belief or world-view.

In Afikpo masked performance, the mask functions as a "poetic license" for the performer, which enables him to escape individual and collective 
judgment because his identity remains open and closed. Okumkpo performers are known and recognized before, during and after public performance. Since it is traditional theatre whose performer is a social critic and activist, the mask transforms him to a "messenger of the gods" whose message cannot be challenged by mortals. With the mask, he is not only a messenger of Obasi ("Afikpo supreme God"), but also Okumkpo is transformed to Maa ("spirit") that is a spirit from the spirit world. Okafor (1991) puts it thus: "a taboo protects the actor and aids the depiction of the supernatural quality which the mask invests the character" (p. 44). The performance is inter alia accompanied with satirical songs. Ododo (2009, p. 38) says that the satirical pedagogical and philosophical nature of these songs projects the core essence of the [performance], which focuses on moral uprightness, equity and social justice, aimed at social transformation." African theatre is similar to other oral genres in providing a social function and Bakary Traoré observes it and asserts that African theatre is "a mirror of life" (Barrios, 1997, p. 9), reminding us of Augusto Boal's "committed theatre". Afikpo masquerade performance is characteristic in its thematic motif of a societal watch-dog, engaging in social criticism and inculcating moral consciousness in the society, explaining the "police function of the mask". Onwuzolum (1977) describes the Afikpo Okumkpo play as a performance that ridicules members of the public. In this way, the masks act as a check on public morality (p. 79). Thematic materials are consequently derived from societal evils, deviant behaviors, and taboos chronicled by the performer who gives them temporal and spatial definitions. The mask attracts acclamation and criticism, protagonists and antagonists, and admirers and haters. Oppositions to mask and masking came from early African converts (Obuh, 2005, p. 3) and missionaries who sew its rituals as satanic and idolatrous. Gender issues and new wave of Pentecostalism keep undermining mask performances in Africa, including those of Afikpo, Southeastern part of Nigeria, thereby increasing their risk of extinction except the possible demythologization of their sacredness.

\section{Demythologization of Sacred Traditional Performances}

Afikpo oral traditions including Okumkpo masquerade performance are highly gendered because of their metaphysical compositions. Though some masquerades are designed feminine in costumes, gestures and cultures, women are forbidden from having close contacts with masked performers, unlike traditional wrestlers whose exploits are celebrated with pomp and pageantry by women. The reason emerges from the fact that Okumkpo is 
structurally a gendered performance, organized by Afikpo popular Ogo cult that is typically masculine but never antifeminine. Dissimilar from Egungun masquerade that was used for feminine oppression (Na'allah, 1996, p. 67), Afikpo cultic masquerades such as Okpaa, are fond of women who sing and watch them perform in front of homes and open spaces in the village. Okumkpo public theatre and other masked displays are no longer enjoying mass admiration due to undeniable forces of modernism and religion. In the 1980s, masquerade dances such as Okpaa were still popular, though facing the forces of Pentecostalism whose leaders censured the participation of their members. This open criticism of Ogo cult and its activities led to ChristianOgo disturbances of December 1987 which witnessed the burning down of houses belonging to Afikpo Christians in Ugwuegu and other parts of Afikpo. In a telephone interview, Mbey (2012), admitting that modernism and religion have played a role in militating against the performance of Okumkpo and other masked rituals of Afikpo origin, says:

Western education is responsible for the misunderstanding of Afikpo masked performances because the new generation believes that their knowledge is superior to that of the old generation. This is worsened by the freedom of religion in the Nigerian constitution since the Afikpo Christian-Ogo White Paper admits that Ogo cult is a religion. However, Christians are right to underscore that ritualistic practices that precede the performances make them idolatrous, unfortunately the socio-cultural values inherent in this tradition are grossly ignored ${ }^{1}$.

The White Paper which Chief Mbey mentions is a product of the interreligious committee set up to broker peace between Christians and Ogo adherents in Afikpo after the religious disturbances. He recognizes the fact that the ritualistic practices of this performance hinder the participation of Afikpo Christians. In addition to lack of patronage from Christians as audience, Christians cannot be part of the cast of Okumkpo because most of them are non-initiates or Unuena as they are popularly called in Afikpo. Agwo (2006, p. 6) advocates the expunging of the fetish aspects of the initiation [into the Ogo cult and its activities] so that Afikpo Christians may be accommodated. For example, M. Uche Ogbonna $\mathrm{Uche}^{2}$ is an indigene of Afikpo, a businessman and Pentecostal believer. As a non-initiate into the Ogo cult due to his Christian beliefs, he swore that none of his male children would be initiated into the cult. In a telephone interview, M. Uche could easily remember the date of Christian-Ogo clash because he could have been a victim. Though oral traditions are generally seen as cultural heritage and identity, proactive demythologization or deritualization will disperse the cloud of mysticism 
surrounding Afikpo cultural performances, open them up to aesthetic innovations and give them wider acceptability or audience. There has been a mass rejection of masquerade performances and other traditional festivals by Pentecostal Christians who describe them as pagan practices. This phenomenon is prevalent in many urbanizing communities. Gore (2008, p. 60) also acknowledges the denunciation of Uga masquerade by Uga Christians. Afikpo oral traditions, besides their rituals and sacrifices that are perceived as antagonistic to Christian beliefs, are characteristically sexually gendered.

Most cultural practices that involve rituals and masquerades in Afikpo are gender sensitive because these masquerades are linked to the spirit world where man's hegemony predominates. Afikpo masquerades are the prerogatives of $O g o$ men cult. Idam (2006, p. 15) defines $O g o$ as "a rest house, meeting house and a store for masks and other cultic artifacts. It is regarded as a sacred place, so sacred that the non-initiates and women can neither enter there nor call someone out of the house". Ottenberg (2005, p. 96) acknowledges the fact that men's society or Ogo cult, associated with the masquerades, is a powerful way of controlling women's behavior. No woman is permitted to touch sacred masquerades in Ehugbo society as it remains a taboo. As Nzekwu (1981, p. 132) puts it:

Women are excluded from sharing in the secrets [of masquerading] for they are weak and fickle and are therefore not fit to take part in them [masquerades]. They [women] are also mysterious and sometimes unclean. They cannot therefore approach these ancestral manifestations, whose character is diametrically opposed to their own. Any meeting between them would have adverse effects on both parties. Much harm would come to the women and masquerades would lose something of their virtue.

Nzekwu's submission results from myths surrounding masquerades and he calls masquerades "ancestral manifestations". Afikpo Ogo cult members believe that when there is a bodily contact between a masquerade and a woman, curses are triggered off against the woman who is compelled to appease the gods of the land with numerous blood sacrifices. This cultural patriarchy is highly but secretly resented by some women who used a singing group "to make up songs with music that sounded something like the men's secret society songs" (Ottenberg 1981, p. 96). This artistic type of resentment as underlined by Ottenberg is no longer used in modern Afikpo, rather masquerades and their performances are no longer enjoying feminine patronage as it was in the 1980s. Consequently, demythologization of Afikpo oral traditions will ensure feminist tolerability and participation. It will redefine the relationship 
between Afikpo womenfolk and its sacred performances. Demythologization of Afikpo sacred traditional performances will ensure that ritualistic aspects of the tradition inimical to Afikpo women and Christians are avoided. If demythologized, these performances will experience cultural syncretism thereby acquiring the potentials of becoming a cultural tourism.

Cultural conformists, paranoid of hybridity, will summarily see cultural syncretism as a process of loss of culture, yet culture should not be seen as what Said (1993, p. xiv) calls "a protective enclosure" that is "antiseptically quarantined from its worldly affiliations", but people should allow their culture connect them with "pleasure and profit". As the "tourism of culture" becomes the nature of postmodern societies, thereby increasing transculturalism, cultures that refuse to embrace pragmatic transformations will not stand the test of time. To connect to Said's cultural "pleasure and profit" which points to commodification of cultures for economic gains, Ndi-Ehugbo must demythologize and demystify Okumkpo masked performance and other Afikpo oral traditions according to postmodern realities of man, thereby commercializing and commodifying them as tourism products. For preservation of Nooraa performance, Iwasawa (2008, p. 7 ) admits that the westernization of Thai traditional display was proactive and pragmatic because it enabled systematic elimination of some traditional parts such as the ritual performance and employment of modern instruments and styles in order to target younger audiences. Enekwe (1981, p. 154) acknowledges the similarities between African and Asian traditional dramas in areas of ritualization and stylization. In the same vein, Westernization of Okumkpo masquerade performance has also become necessary in order to contend with the forces of modernism. Though Okumkpo uses traditional musical instruments such as wooden drums or ikoro, bells, etc, there is need to augment and appropriate modern musical tools for vocal amplification and symphonic vocalization.

\section{Conclusion}

Okumkpo public performance originated from Ogo secret society which is a patriarchal union of male initiates of Afikpo indigenes, therefore its preparatory activities are shredded in secrecy. However, in addition to its role of committed "social seer" that describes its social function, Okumkpo's theatrical manifestation has a therapeutic function in mixed audiences, who come from far and near in order to watch the live performance and its aesthetics. To open up the performance to international appeal and audiences, the demythologization, as we have discussed, must also take cognizance of the question of 
language. Okumkpo narrative and its intervallic songs are rendered in Ehugbo language, a local dialect spoken by Afikpo people. This language is fundamentally used as a medium of communication in Okumkpo masquerade. As we have seen in the case of Nooraa traditional performance of Southern Thailand and Northern Malaysia that has undergone a westernization (Iwasawa, 2008), modernization entails technical and aesthetic changes, including the use of English language as a Lingua Franca, contemporary costumes, modern stage with props and musical equipment, and artistic professionalization of Okumkpo traditional theatre, not just the purging of its rituals and mysticism. Afikpo oral traditions such as festivals, fishing contest, traditional wrestling and Okumkpo can be developed beyond their deployment as cultural markers; they can be commoditized and commercialized as tourism products thereby becoming high income earners for the nation and immediate community. In the face of global mobility of culture, there is ontological and epistemological shifting of the notion of culture due to conspicuous postmodern forces of transculturation. It now goes beyond the question of identity. The idea of "tourism of culture" has given rise to commodification of cultures by proactive and pragmatic societies of the world. There is need to repackage oral traditions for the socio-economic development of Africa and third world countries of the world.

\section{References}

Adejumo, A. A. (2009). Technologizing oral texts: Archiving yoruba oral literature through new technological media, Lamina, 20:1-16.

Afikpo Today (2005). Community news: Okumkpo Unwana displays. Afikpo Today, 3, January-June, 17.

Agovi, K.E. (1990). The origin of literary theatre in colonial Ghana, 1920-1957. Research Review NS, 6:1-23.

Agwo, G. A. (2006). Isu Ubu Ehugbo (Initiation) at the cross-roads. Afikpo Today, 3:13-15.

Aja, R. O (2005). A History of Afikpo Circa 1600. Lagos : Mbey \& Associates (Nig) Ltd.

Attikpoé, K. (2009). La représentation du passé dans la littérature africaine pour la jeunesse. Cabiers de la Recherche en Éducation, 11 : 151-159.

Barrios, O. (1997). A Reflection on the similarities of the black theatre movement in the USA and in South Africa. Atlantis, XIX: 7-13.

Cheng Chang, B. À (1980). Women's status in Afikpo Ibo society. Unpubl.

MA Dissertation, Graduate Faculty, Texas Tech University. 
Clark, J. P. (1981). Aspects of Nigerian drama. In Y. Ogunbiyi (Ed.) Drama and Theatre in Nigeria (pp.57-74). Lagos : Nigerian Magazine.

Chuku, G. (2001). Recovering the voices and life histories of Igbo women: Sources and methodological considerations. Unpubl. paper presented at 2001 Dartmouth College \& York University/UNESCO Nigerian Hinterland Project's Workshop on The Atlantic Crossings: Women's Voices, Women's Stories from the Caribbean and the Nigerian Hinterland.

Coker, O. \& Coker, A (2008). Folklore as folklaw in Yoruba indigenous epistemology. Afroeuropa, 2 (1).

Enekwe, O. E. (1981). Myth, ritual and drama in Igboland. In Y. Ogunbiyi (Ed.) Drama and Theatre in Nigeria (pp.149-163). Lagos : Nigerian Magazine.

Elechi, O. O. (2003). Extra-Judicial killings in Nigeria: The case of Afikpo town. Unpubl. Paper presented at the 2003 International Society for the Reform of Criminal Law's $17^{\text {th }}$ Conference. the Hague, Netherlands.

Gore, G. (2008). "Burn the Mmonwu": Contradictions and contestations in masquerade performance in Uga, Anambra State in Southeastern Nigeria. African Arts, 60-73.

Hunte, N. (2007). Notions of myth, gestures of masquerade: Theatre of memory in Derek Walcott's Omeros and Tom Morrison's Beloved. Shibboleths: A Journal of Comparative Theory, 2:58-69.

Huttunen, T. (2002). "From "word-images" to "chapter-shots": The imaginist montage of Anatolij Mariengof. Sign Systems Studies, 28: 181-198.

Idam, P. A. (2006). "Re : Afikpo culture and tradition and the Christian churches. Afikpo Today, 3:13-15

Iwasawa, T. (2008). Preservation of traditional art: The case of the Noora performance in Southern Thailand. Wacana Seni: Journal of Arts Discourse, 7:1-22.

Jacob, O. U. (2012). Issues in Theatre Practice. Uyo: MEF Publishers.

Khan, A. W. (2009). Paradigm of social aesthetics in Themne oral performance. Oral Tradition, $24: 143-159$.

Kehinde, A. (2003). Intertextuality and the contemporary African novel. Nordic Journal of African Studies, 12: 372-386.

Kesteloot, L. (1978). Anthologie Négro-africaine. Verviers : Les Nouvelles Éditions Marabout.

Lambert, J. M. (2005). Ama Ata Aidoo's Anowa: Performative practice and the postcolonial Subject. Unpubl. MA Dissertation, the Department of Theatre, Faculty of Miami University, Ohio.

Musa, R. A. (2006). The drama and theatre of Wole Soyinka. An Encyclopaedia of the Arts, 11: 216-129.

Na'allah, A-R. (1996). The origin of Egungun: A critical appraisal. African Study Monographs, 17:59-68.

Nzekwu, O. (1981). Masquerade. In Y. Ogunbiyi (Ed.), Drama and Theatre in Nigeria (pp.59-68). Lagos : Nigerian Magazine. 
Obuh, S. O. (2005). The paradox of masks: A call for the return to masking aesthetics in contemporary theatre. Retrieved from www.bu.ac.th/knowledgecenter/ epaper/...

Ododo, S. E (2009). The playing aesthetics of Ebiran Ekuechi Facekuerade festival. Perfformio, 1:28-45.

- S. E. (2001). Theatrical aesthetics and functional values of Ekuechi masquerade ensemble of the Ebira people of Nigeria. African Study Monographs, 22:1-36.

Ojaide, T. (2009). Examining canonization in modern African literature. Asiatic, $3: 1-19$.

Olorunyomi, S. (1996). Theatre in Niger valleys. African Quarterly on the Arts, 1: 60-75.

Okafor, G. C. (1991). Behind the inscrutable wonder: the dramaturgy of the mask performance in traditional African society. Research in African Literatures, 22:39-52.

Onwuzolum, C. (1977). The Ritual-Theatricality of Igbo masks and masquerades. Unpubl. MA Dissertation, Faculty of Graduate Studies, the University of British Columbia, Canada.

Osundare, N. (2007). The Writer as Righter. Ibadan : Hope Publications.

Ottenberg, S. (1968). Double Descent in an African Society: The Afikpo VillageGroup. Seattle \& London : University of Washington Press.

—, (1970). The analysis of an African play. Research Review, 7: 66-84.

- (2005). Memories of the past times at Afikpo. Afikpo Today, 3: 94-97.

Rotimi, O. (1981). The drama in African ritual display. In Y. Ogunbiyi (Ed.) Drama and Theatre in Nigeria (pp.77-80). Lagos: Nigerian Magazine.

Said, E. (1993). Culture and Imperialism. New York: Vintage Books.

Shivers, N. D. (2009). Fashion as performance: Influencing future trends and building new audiences. Unpubli. Paper presented at Inter-Disciplinary Net's $1^{\text {st }}$ Global Conference Fashion-Exploring Critical Issues.

Shuman, A. (2003). Oral history. Oral Tradition, $18: 130-131$.

Suh, C. J. (2002). Some considerations in the translation of African drama. Meta: Revue des Traducteurs/Meta : Translator'Journal, 47: 370-375.

Tomaselli, K \& Eke, M. (1995). Perspectives on orality in African cinema. Oral Tradition, $10: 111-128$.

\section{Notes}

1. Extract of a telephone interview with Chief Gabriel Agha Mbey in 2012, an elder in Ugwuegu community of Afikpo who is known for his vast knowledge in Afikpo history and tradition.

2. M. Uche Ogbonna Uche is a typical example of a non-initiate who has suffered persecution from his community due to his refusal to be initiated into the Ogo cult of Afikpo. He lives in Awka in Anambra State of Nigeria and is married to the author's aunt. 